\title{
Dossiê: Simetrização, Hibridismo e Agência na Antropologia
}

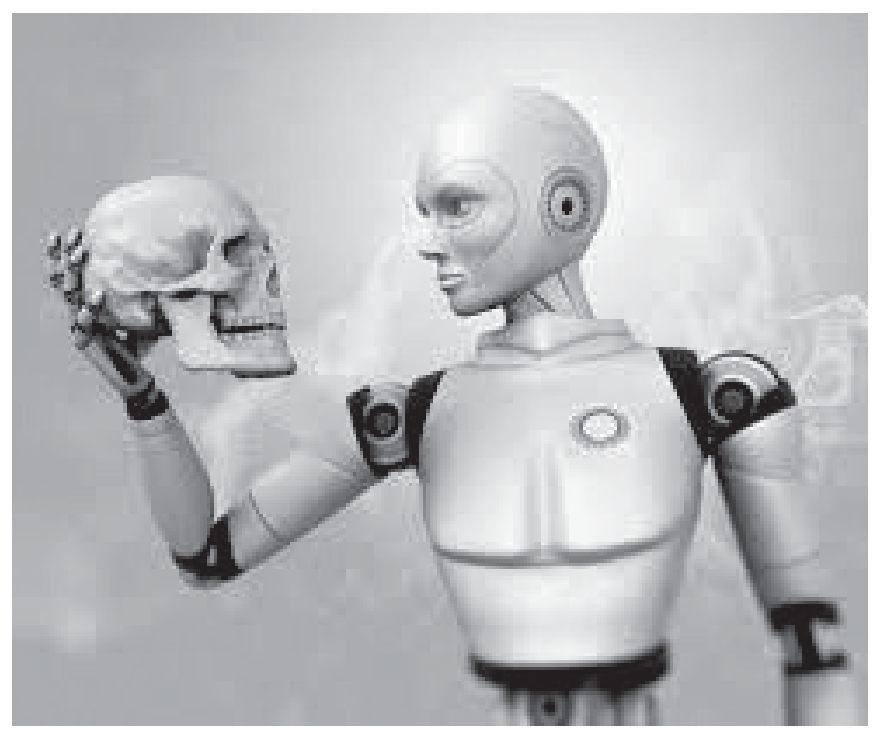

Organizadores

Theophilos Rifiotis

Jean Segata

Oscar Calavia Saez 


\section{Apresentação}

\section{Theophilos Rifiotis}

Universidade Federal de Santa Catarina, Florianópolis, Brasil

E-mail: t.rifiotis@ufsc.br

\section{Jean Segata}

Universidade Federal do Rio Grande do Norte, RN, Brasil

E-mail: jeansegata@gmail.com

\section{Oscar Calavia Saez}

Universidade Federal de Santa Catarina, Florianópolis, Brasil

E-mail: occs@uol.com.br 

presente dossiê, intitulado Simetrização, Hibridismo e Agência na Antropologia, tem o objetivo de difundir os resultados das duas primeiras edições do Seminário Mapeando Controvérsias Contemporâneas, organizadas pelo Grupo de Pesquisa em Antropologia do Ciberespaço (GrupCiber) do Programa de Pós-graduação de Antropologia Social da Universidade Federal de Santa Catarina, em 2013 e 2014, com apoio da CAPES, PPGAS/UFSC e da Direção do Centro de Filosofia e Ciências Humanas/UFSC. A terceira edição, "Ciência, Biotecnologia e Cibercultura", tem lugar em novembro de 2015 com apoio do CNPq, CAPES, FAPESC e do PPGAS/UFSC.

Na primeira edição, o tema do Seminário foi "Humanos e Não Humanos na Antropologia" e na segunda, o tema é aquele que dá nome a este dossiê. Somadas, as duas primeiras edições do seminário reuniram uma amostra significativa de pesquisadores de diversas instituições do Brasil e do exterior, como UFMG, UnB, Museu Nacional/UFRJ, UFRGS, UFRN, UFSC e Université de Nanterre - Paris X. As reflexões então apresentadas são a substância do presente dossiê, cujos artigos analisam os efeitos que as discussões sobre simetria, hibridismo e agência vêm tendo na teoria e na etnografia contemporânea - especialmente quanto ao tratamento das técnicas, com relação 
aos animais, aos espíritos, aos artefatos e às suas associações/relações com os humanos. Nossa pretensão é estabelecer tópicos para uma revisão da disciplina; e identificar os efeitos que a chamada Virada Ontológica - aliada à Teoria Ator-Rede - tem produzido nas pesquisas antropológicas recentes. Cabe também salientar que a discussão proposta, tanto nos seminários quanto no dossiê, ultrapassa a fronteira dos campos específicos e foca tendências comuns no pensamento antropológico contemporâneo. Buscamos, assim, o diálogo entre as antropologias oriundas dos mais diversos campos de investigação e dos mais diferentes centros e programas de pesquisa.

Nesse mesmo sentido, desde 2010, foi promovida uma série de iniciativas paralelas que contribuíram para o tipo de discussão aqui proposta. A primeira experiência foi ensaiada por Jean Segata, Bárbara Arisi e Theophilos Rifiotis no evento intitulado II Jornadas Antropológicas da UFSC, com o GT "A Actor-Network Theory e a Antropologia: desdobramentos pós-sociais, que reuniu trabalhos dos mais diversos campos de pesquisa, em torno da Teoria Ator-Rede. Em 2013, ano do I Seminário Mapeando Controvérsias, Theophilos Rifiotis e Jean Segata organizaram um GT na $X$ Reunião de Antropologia do Mercosul (RAM), que aconteceu na cidade de Córdoba/Argentina. O Grupo de Trabalho (GT) foi intitulado Por uma Antropologia do Contemporâneo: simetria, múltiplas agências e a etnografia a partir de uma perspectiva sociotécnica, nesse evento surgiu a oportunidade de conhecer pesquisadores latino-americanos de campos diversificados e, assim, foi possível discutir sobre assuntos de interesse comum diante desses novos rumos do debate. Em 2014, na ocasião da segunda edição do Seminário, organizou-se, com Aírton Jungblut (PUC/RS), um GT na Reunião Brasileira de Antropologia realizada em Natal. Já em 2015 foi organizada uma mesa-redonda, Jusqu'où peut-on aller? Humains et non humains au coeur des politiques ethnographiques, com a professora Sophie Houdart (Paris X). Theophilos Rifiotis coordenou, com Arturo Escobar (University of North Carolina at Chapel Hill, EUA), o Simpósio 65 Antropologia y Cibercultura: Políticas etnográficas en redes sociotécnicas, no IV Congreso Latino-Americano de Antropología (México). Igualmente, em 2015, as nossas iniciativas incluíram duas mesas redondas, na reunião da ANPOCS em Caxambu (Políticas Etnográficas: Humanos e Não-hu- 
manos na Antropologia), e na XI RAM a ser celebrada em Montevideo. Também na XI RAM em Montevideo, Jean Segata coordenou um GT em colaboração com Rosalía Winocur (UNAM) e Theophilos Rifiotis.

Assim, este dossiê é fruto de um extenso labor que, difundindo e aprofundando uma agenda de pesquisa, propiciou também encontros instigantes. Pode-se dizer que este dossiê reúne trabalhos de pesquisadores inspirados nessa perspectiva, com quem dialogamos nesses últimos anos e cujos encontros têm propiciado avanços importantes e contribuído para disseminação e aprofundamento das questões que estão no escopo do Seminário Mapeando Controvérsias. Um desses encontros trouxe a este dossiê casos como o artigo de Sophie Houdart, cujo trabalho aqui apresentado nos convida a uma incursão antropológica pelo Centro Europeu de Pesquisa Nuclear (CERN), especificamente no laboratório Large Hadron Collider (LHC), o maior e mais conhecido acelerador de partículas construído, com o objetivo de descrever as operações por meio das quais as partículas e o cosmos são comensuráveis para os corpos técnicos e científicos daquele laboratório. A autora, inspirada pela obra de Bruno Latour, nos apresenta e realiza aquilo que se poderia chamar de uma "descrição explicativa", um ensaio de escrita que detalha e descreve o modo pelo qual, naquele gigantesco laboratório, e com quais elementos são produzidos "dados" que devem permitir elucidar os "[...] primeiros princípios que governam o nosso universo $[\ldots]$ ", ela mostra, também, como os humanos e os não humanos interagem na produção do conhecimento científico.

A seguir, o trabalho de Guilherme Sá nos convida para uma reflexão sobre o modo em que a categoria "simetria" (tomada de Bruno Latour e da Teoria Ator-Rede) tem sido acionada na antropologia no Brasil. O que lhe permite sugerir um protocolo para a pesquisa sobre as ciências que considere a especificidade da (não) modernidade do Brasil.

$\mathrm{O}$ artigo de Iara Souza trata de um tema que vem ganhando espaço na antropologia e nas Ciências Sociais: o das ontologias múltiplas no contexto da chamada Virada Ontológica. A partir das contribuições de Annemarie Mol, a autora problematiza essa noção e aborda consequências políticas. 
O próximo artigo, de Bernardo Lewgoy, Caetano Sordi e Leandra Pinto, propõe um exame do campo da proteção animal em Porto Alegre (RS) a partir de um ponto de vista antropológico e etnográfico, inspirado na multi-agência e nas redes sociotécnicas de Bruno Latour, dentre outras matrizes. O artigo conclui que o exercício de domesticação, contido nas iniciativas de proteção animal analisadas, está marcado por uma tentativa de disciplinar e de higienizar o espaço público e de educar os seres humanos para o convívio com membros não humanos das famílias, tornando-os responsáveis (em sentido moral, psicológico e legal) pelas suas novas famílias multiespecíficas.

Finalmente, João Roberti Junior, Diógenes Cariaga e Jean Segata projetam todo esse conjunto de controvérsias sobre o próprio estatuto teórico e metodológico da antropologia, examinando o lugar que a descrição (etnográfica, cartográfica, de modos de existência) tem na produção antropológica contemporânea. A antropologia se apresenta como uma (in)disciplina preocupada com a relação imprecisa entre campo e escrita e, assim, em certo sentido, resume o conjunto de novas luzes e dúvidas que essa atenção a simetrias, hibridismos e agências traz para o pensamento de hoje.

Desejamos uma excelente leitura! 